\title{
The Effects of Nitrogen Influxes on the Photosynthesis and Growth Rates of Air Potato
}

\author{
Vraj Parikh \\ Lincoln Park Academy, 1806 Avenue I, Fort Pierce, Florida, 34950, USA; 5620402630@stlucieschools.org
}

ABSTRACT: Nutrient pollution occurs when excess nutrients such as nitrogen are released into the environment. Nutrient pollution can have serious environmental consequences such as contributing to toxic algal blooms. This pollution becomes increasingly problematic as population increases. Photosynthesis occurs in plants to produce glucose to fuel growth, and nitrogen is important to this process as it increases chlorophyll count and $\mathrm{CO}_{2}$ gas exchange. Excess nitrogen can lead to an increase in plant growth, which is problematic if the plants are an already fast-growing, invasive species. Air potato is one such plant, native to tropical Asia and Africa, but invasive to Florida's ecosystems. A novel virus complex (Dioscorea mosaic virus and air potato virus 1) co-infects some air potato plants, but its impact on the plants is unknown. In a greenhouse, healthy and virus-infected plants were grown under base nitrogen (control) and high soil nitrogen environments. Numbers of leaves, leaf area, and photosynthetic rate were calculated one week after the addition of nitrogen. These data were collected again 1 month later. A two-way ANOVA was conducted to determine the relationship between plant health and fertilization on photosynthesis and growth rate. Fertilizer significantly increased initial photosynthetic rate, while plant health did not significantly affect growth rate or photosynthetic rate.

KEYWORDS: Plant pathology; Environmental nutrient pollution; Air potato; Plant viruses; Invasive species.

\section{- Introduction}

Dioscorea bulbifera L. (air potato) is an invasive vine native to tropical Africa and Asia. It can grow rapidly, up to $20 \mathrm{~cm}$ daily, and can smother out vegetation and kill it, thereby displacing native plant species. These vines reproduce vegetatively and rapidly with aerial bulbils and tubers. A novel virus complex has recently been discovered, consisting of the viruses Dioscorea mosaic virus (genus Potyvirus) and air potato virus 1 (genus ampelovirus). ${ }^{1}$ These viruses can co-infect D. bulbifera, causing air potato leaves to develop a mosaic pattern (Figure 6). The effects that this virus complex has on the growth of air potato plants are unknown and is one of the focuses of this investigation.

Excess nutrients come from many sources including the natural weathering of rocks and soil or from human overuse of fertilizers. ${ }^{2}$ This increase in the amount of nutrients can contribute to dead zones in water which lack oxygen or cause an increase in the amount of toxic algal species in affected areas. ${ }^{3}$ The rate of nutrient pollution is increasing, especially in highly populated areas like Florida, and may be especially problematic when it comes to invasive plant species.

Nitrogen $(\mathrm{N})$ is a biologically important element for plants because plants invest nitrogen a major component of chlorophyll, the pigment responsible for photosynthesis, and of amino acids. ${ }^{4}$ Photosynthesis is a biochemical process performed plants in which they use sunlight to synthesize sugars from $\mathrm{CO}_{2}$ and $\mathrm{H}_{2} \mathrm{O}$. Photosynthesis in plants involves the green pigment chlorophyll (which is responsible for absorbing energy from sunlight), with the products glucose $\left(\mathrm{C}_{6} \mathrm{H}_{12} \mathrm{O}_{6}\right)$ and $\mathrm{O}_{2}$. Previous studies in rice (Oryza sativa L.) have shown that a higher $\mathrm{N}$ supply increased leaf $\mathrm{N}$ and chlorophyll con- tent. ${ }^{5}$ A higher $\mathrm{N}$ supply can significantly increase the amount of carbon gained from $\mathrm{CO}_{2}$, leading to an increase in glucose production in plants with a higher $\mathrm{N}$ content. ${ }^{4}$ The impact of nitrogen supply on the growth of air potato plants is unknown, so this is another major focus of the investigation.

The impact of the Dioscorea mosaic virus and air potato virus 1 complex on air potato plants under both "base" and high-level nitrogen environments was investigated. The hypothesis of the experiment is that air potato plants will positively respond to a higher $\mathrm{N}$ content, regardless of plant health. A higher supply of $\mathrm{N}$ increases leaf $\mathrm{N}$ and chlorophyll content and increases $\mathrm{CO}_{2}$ gas exchange in plants. An increased leaf $\mathrm{N}$ supply, chlorophyll content, and a higher gas exchange rate will contribute to an increased photosynthetic rate of air potato plants. Therefore, a higher $\mathrm{N}$ content will result in an increased growth rate in the air potato plants due to an increased photosynthetic rate. This study will also help determine if the virus complex will have varying impacts on the vines under different soil nutrient conditions.

\section{- Results and Discussion}

Fertilizer significantly lowered the rate of photosynthesis one week after administration to plants $(\mathrm{p}=0.0057)$ (Figure 1 ). Photosynthesis was not statistically affected by plant health (virus or healthy) $(\mathrm{p}=0.078)$ one week after application (Figure 1). However, because the $\mathrm{p}$-value is very close to 0.05 , there may be a trend in which the virus complex decreases photosynthetic rates of air potato plants. In both high-N and base- $\mathrm{N}$ environments, the healthy plants had a higher rate of photosynthesis than the infected plants. This trend was more prominent in the base $\mathrm{N}$ treatment (Figure 1). 


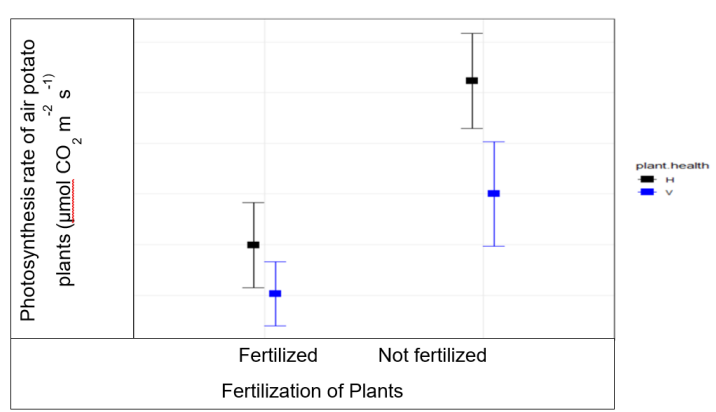

Figure 1: Photosynthesis rate of air potato plants 1 week after being treated with nitrogen fertilizer. Fertilized plants had a significantly lower initial photosynthesis rate than their non-fertilized counterparts $(p=0.0057)$.

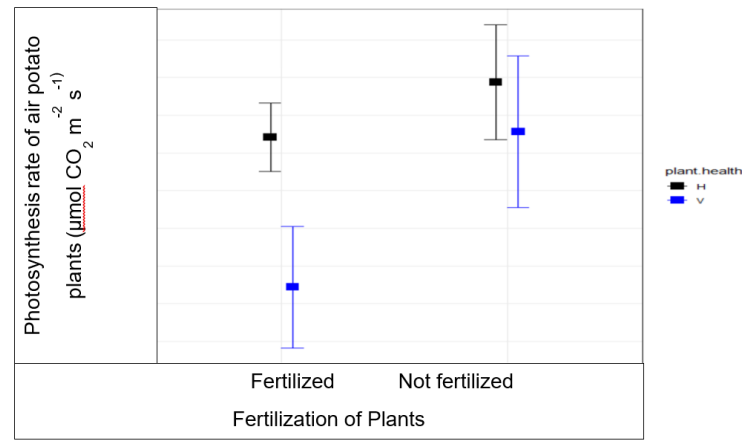

Figure 2: Photosynthesis rate of air potato plants 1 month after being treated with nitrogen fertilizer. Virus infected plants were observed to have a lower photosynthetic rate months after addition of the nitrogen and tended to have a lower photosynthetic rate than healthy plants in both $\mathrm{N}$ levels $(\mathrm{p}=0.075)$.

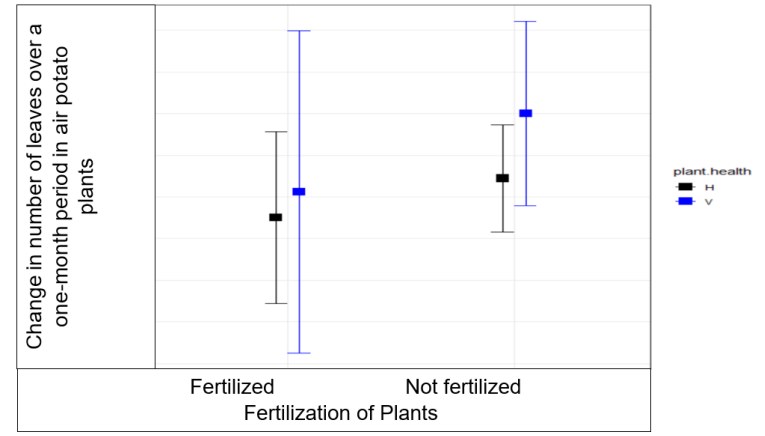

Figure 3: Change in leaf number per plant over one month under base and high $\mathrm{N}$ soil levels. No differences in leaf number across fertilizer $(\mathrm{p}=0.58)$ or plant health $(\mathrm{p}=0.66)$ treatments.

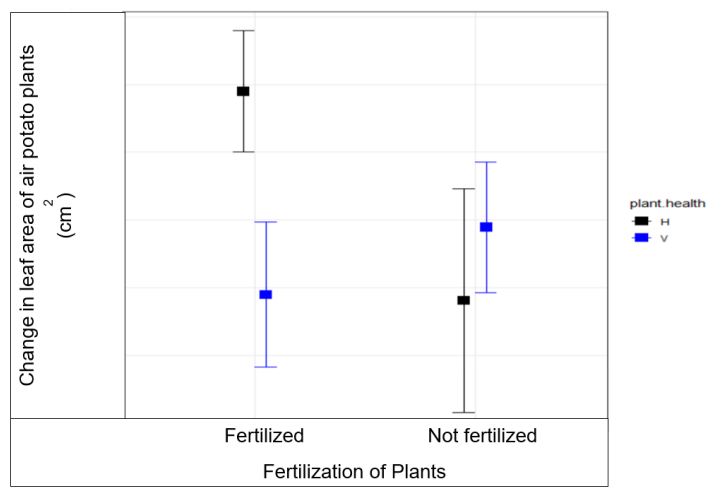

Figure 4: Change in average leaf area per plant over one month under base and fertilized treatments. No differences in leaf area were found across fertilizer $(\mathrm{p}=0.38)$.
The initial photosynthetic rates of air potato plants were significantly lower in the plants that received fertilizer $(\mathrm{p}=$ 0.0057). The initial photosynthetic rate of the plants was not affected by plant health $(p=0.078)$. One month after fertilizer was added, the virus infected air potato plants were observed to have a lower photosynthetic rate than their healthy counterparts $(p=0.075)$. However, the photosynthetic rate of the plants one month after fertilization was not significantly affected by fertilizer treatment $(p=0.062)$. Fertilizer treatment did not significantly affect the change in the number of leaves $(p=0.57)$ or the change in leaf area in the air potato plants ( $p$ $=0.37)$. Furthermore, the virus complex did not significantly impact the change in leaf number $(\mathrm{p}=0.66)$ or leaf area $(\mathrm{p}=$ 0.47) of the air potato plants.

An influx of nitrogen will significantly decrease the initial photosynthesis rate of air potato plants, as shown by (Figure 1., $p=0.0057)$. In this study, an influx of nitrogen did not significantly affect the photosynthesis rate of air potato plants 1 month after the nitrogen input (Figure 2., $\mathrm{p}=0.062$ ) or the change in leaf number (Figure 3., $p=0.58$ ) or leaf area (Figure 4., $\mathrm{p}=0.37$ ) of the air potato plants. The virus complex also did not significantly affect the photosynthesis rate of air potato plants (Figure 1., $p=0.078$; Figure 2, $\mathrm{p}=0.075$ ), change in leaf area (Figure 3., $p=0.47$ ), or the numbers of leaves (Figure 4., $\mathrm{p}=0.66$ ) per air potato plant.

It was observed that virus-infected plants had lower photosynthetic rates, change in the number of leaves, and leaf area at the end of the experiment. If the experiment was conducted over a longer period of time, it is likely that virus-infected plants would've had significantly lower photosynthetic rates than the healthy plants because the p-values for plant health (0.077), initial photosynthetic rate (0.078), and photosynthetic rate 1 month after fertilization (0.075) were all close to 0.05 . If this study was conducted over a longer period, or if more than five leaves per plant were tested, it is likely that the photosynthetic rates of the infected plants would have been significantly lower and therefore, the growth rate of the infected air potato plants would have been negatively impacted as less food is being produced by photosynthesis that is needed for plant growth.

The fertilized plants responded negatively to nitrogen fertilizer, as the initial photosynthesis rate was significantly lower in the fertilized plants than in the non-fertilized plants. The specific effects of nitrogen influxes on air potato plants is unknown, however, it is known that high levels of nitrogen fertilizer on plants are favorable to aphid production, which is why many in the agricultural industry are advised to never use more nitrogen than necessary for their plants. ${ }^{6}$ During the study, several aphids were observed on the undersides of the leaves of the air potato plants, and the virus complex infecting the plants contains a potyvirus (Dioscorea mosaic virus); aphids have been known to spread several types of potyviruses to plants and are hypothesized to be the vector that spreads the virus complex to the air potato plants. ${ }^{1}$ Therefore, it is possible that aphid feeding may have negatively impacted the fertilized air potato plants one week after the application of fertilizer. Because the $\mathrm{p}$-value for fertilizer treatment one 
month after fertilization was 0.062 , which is close to 0.05 , the aphid feeding may have negatively impacted the fertilized plants, but its effects may have reduced due to loss of nitrogen in the soil from sources such as denitrifying bacteria or leaching which caused the aphids to be less attracted to the air potato plants.

\section{- Conclusion}

Nitrogen pollution significantly decreases the initial photosynthesis rate of air potato plants. However, this effect does not last, as nitrogen pollution does not significantly affect the growth rate or the photosynthesis rate of air potato over time. The virus complex consisting of Dioscorea mosaic virus and air potato virus 1 does not significantly affect the growth rate or photosynthesis rate of air potato plants. Further studies should be done to investigate the long-term effects of nitrogen on healthy and virus-infected air potato plants.

\section{- Methods}

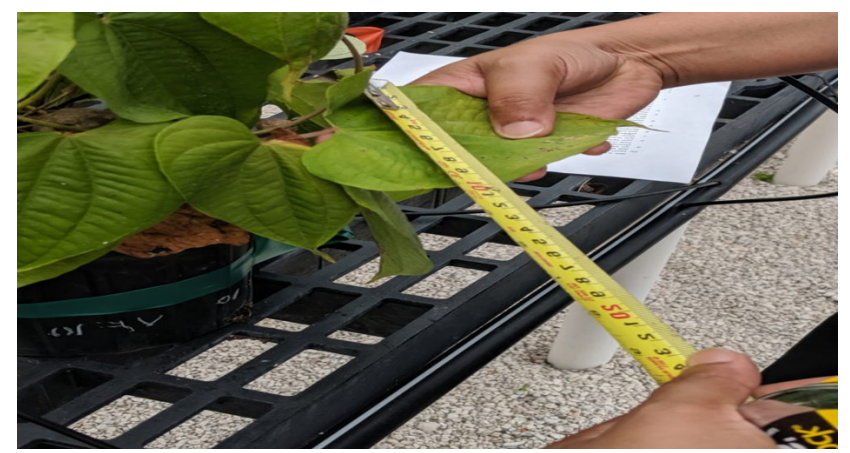

Figure 5: Measuring the width of an air potato leaf (photo taken by researcher).

Thirty-six (36) Dioscorea bulbifera plants were used in the study: 18 plants were infected with the virus complex (9 of these plants received nitrogen-based fertilizer, 9 did not) and 18 D. bulbifera plants were not infected with the virus complex ( 9 plants received nitrogen-based fertilizer, 9 did not). The plants were arranged in a randomized complete block design (RCBD) layout to control variation and prevent statistical bias. After arranging the plants in an RCBD layout, $6 \mathrm{~g}$ of solid urea fertilizer (N-P-K/Nitrogen-Phosphorous-Potassium ratio: 46-0-0) was added to each plant receiving nitrogen to maximize the amount of nitrogen received and to simulate an influx of nitrogen pollution. Each plant was watered after application. The plants were placed on irrigation to ensure they received a sufficient and consistent supply of water and were kept in a greenhouse to control temperature. The greenhouse was set to maintain a constant temperature $\left(29^{\circ} \mathrm{C}\right)$ and a photoperiod of 14:10 L:D to simulate summer conditions, in which the air potato plants grow best. One week after the addition of nitrogen, the number of leaves per plant were counted and leaf areas of the plants were measured by measuring the lengths and widths (Figure 5-6) of 5 leaves per plant. The approximate average leaf area per plant was calculated by multiplying these measurements for each leaf. The photosynthesis rate of the plants was measured using a Li-COR 6400XT photosynthesis system (Figure 7). Photosynthetic rates were measured by placing a single leaf of the plant inside the chamber. Photosynthetic rate of five leaves per plant were measured $\left(\mu \mathrm{mol} \mathrm{CO}_{2}\right.$ $\mathrm{m}^{-2} \mathrm{~s}^{-1}$ ) and $\mathrm{CO}_{2}$ gas exchange readings were averaged for the 5 leaves in order to analyze the impacts of nitrogen and plant health on photosynthetic rate. After one month, the number of leaves per plant was recounted and average leaf area was recalculated to assess the growth rate of the air potato plants. The photosynthesis of the plants was again measured using the Li-COR 6400XT as described above to assess the long-term photosynthesis of the plants. A 2-way ANOVA (analysis of variance, $\alpha=0.05$ ), (leaf health/nitrogen level) was conducted on the photosynthetic rate and the change in leaf area and number to identify a significant statistical interaction between growth and photosynthetic rate, and leaf health and nitrogen level.

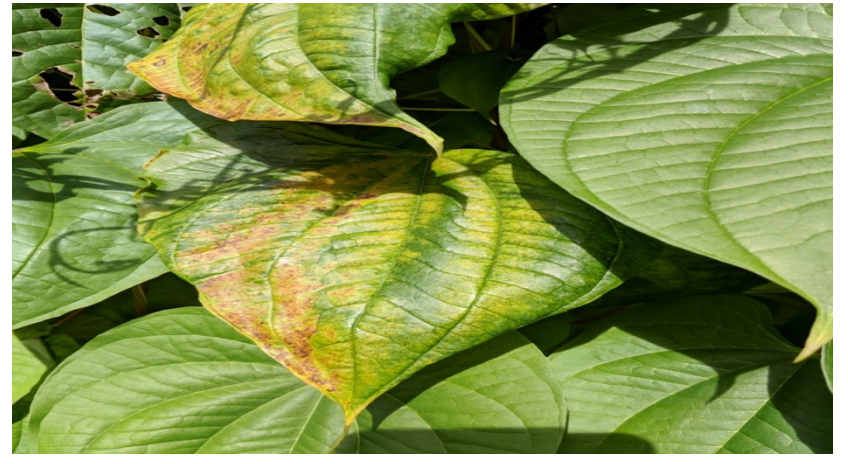

Figure 6: Air potato leaves displaying viral-infection symptoms (photo taken by researcher).

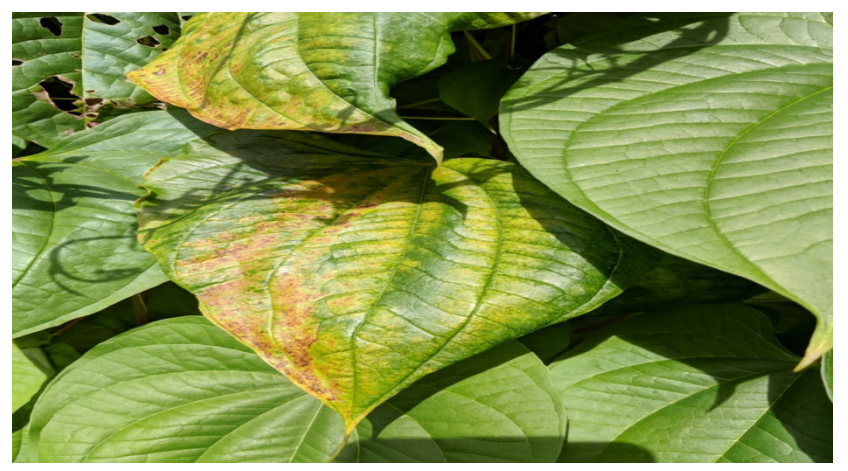

Figure 7: Measuring photosynthesis rate of air potato leaves with the $\mathrm{LI}^{-}$ $\mathrm{COR}^{\mathrm{TM}}$ photosynthesis system (photo taken by researcher).

\section{Acknowledgements}

The author extends his utmost gratitude to Dr. Carey Minteer who mentored him throughout the course of this experiment and allowed him to work in a greenhouse, providing him with the necessary materials and guidance to make this study succeed. The author would also like to extend a great thanks to his science teachers: Mrs. Lina Rao and Ms. Lisa Hevner, for reviewing his presentation of the results and providing additional guidance for the improvement of his work.

\section{References}

1. Kishore K. Dey, Jaylinn Sugikawa, Christopher Kerr, Michael J. Melzer. Air potato (Dioscorea bulbifera) plants displaying viruslike symptoms are co-infected with a novel potyvirus and a novel ampelovirus. Virus Genes [Online] 2019,55,117-121.https://link. springer.com/article/10.1007/s11262-018-1616-6 (accessed June 1,2019).

2. National Ocean Service. National Oceanic and Atmospheric Administration, National Department of Commerce. 
https://oceanservice.noaa.gov/education/kits/pollution/03point source.html (accessed October 15, 2019).

3. United States Environmental Protection Agency. https://www.epa. gov/nutrientpollution/effects-environment (accessed October 20, 2019).

4. Jiali Sun, Mao Ye, Shaobing Peng, Yong Li. Nitrogen can improve the rapid response of photosynthesis to changing irradiance in rice (Oryza sativa L.) plants. Scientific Reports [Online] 2016, 6, Article Number: 31305. https://www.nature.com/articles/ srep31305 (accessed January 15, 2020).

5. Gabor J. Bethlenfalvay, Salah S. Abu-Shakra, Donald A. Phillips. Interdependence of Nitrogen Nutrition and Photosynthesis in Pisum sativum L, 1978. American Society of Plant Biologists $\backslash$ http://www.plantphysiol.org/content/62/1/127 (accessed July 24, 2019).

6. M. L. Flint, UC Statewide IPM Program and Entomology, UC Davis, Laning, C., editor. Pest Notes: Aphids. UC ANR Publicaiton 7404. http://ipm.ucanr.edu/PMG/PESTNOTES/pn7404.html (accessed October 25th, 2020).

\section{- Author}

Vraj Parikh is a rising senior at Lincoln Park Academy who has been working with researchers at a local scientific research facility for 5 consecutive years and has participated in regional and statewide scientific competitions. He intends on applying to University of Florida and majoring in biochemistry. 